\title{
Challenges in Implementation of Fee-Free Basic Education among Public Secondary Schools in Karatu District, Tanzania
}

\author{
Isaya Luvanga \\ Orcid: https://orcid.org/0000-0002-8821-4358 \\ Department of Education Foundations, St. Augustine University of Tanzania \\ Email: isaluvanga62@gmail.com \\ Michaela Mhagama, PhD \\ Orcid: https://orcid.org/0000-0003-1386-4337 \\ Department of Education Foundations, St. Augustine University of Tanzania \\ Email: michaelamhagama@gmail.com
}

Corresponding Mail: isaluvanga62@gmail.com

\begin{abstract}
Copyright resides with the author(s) in terms of the Creative Commons Attribution CC BY-NC 4.0. The users may copy, distribute, transmit and adapt the work, but must recognize the author(s) and the East African Journal of Education and Social Sciences
\end{abstract}

\begin{abstract}
The study sought to establish challenges in implementation of fee-free basic education among public secondary schools in Karatu District using the mixed approach and the convergent parallel research design. Out of 2441 students and 102 teachers from the sampled schools, 97 students and 50 teachers were selected through simple random sampling. Furthermore, 24 school board members, one District Educational Officer and six Heads of School participated in the focus group discussion and the interview schedule. The study revealed that implementation of fee-free education in Tanzania faces challenges which reduce the accuracy of reaching the government expected goals. Among the challenges are poor budget review, lack of financial training and poor accountability by school heads due to limited knowledge on financial management. Based on the findings, the study recommends that the government should ensure that key stakeholders, especially school heads, are well equipped with appropriate skills on financial management in order to curb challenges in implementation of the fee-free basic education among public secondary schools in Karatu District.
\end{abstract}

Keywords: Financial management; fee-free policy; public secondary schools

How to cite: Luvanga, I. and Mhagma, M. (2022). Challenges in Implementation of Fee-Free Basic Education among Public Secondary Schools in Karatu District, Tanzania. East African Journal of Education and Social Sciences 3(1), 102-106. Doi: https://doi.org/10.46606/eajess2022v03i01.0152.

\section{Introduction}

Education plays a crucial role in any country towards achieving sustainable development goals (Caine, 2011). Given the significance of education, countries have been promoting fee-free education policy in financing basic education (URT, 2016). In 1940s, some countries embraced fee-free education policy to ensure children's right to education. International agencies recognized the potentiality of education to children from affluent and marginalized societies. Conversion Covenant on
Economic, Social and Cultural Rights, the Rights of the Child against Discrimination and the African Charter on the Right and Welfare of the Child were engaged in implementation of fee-free policy all over the world (UNESCO, 2014).

On the other hand, Universal Declaration on Human Rights (Article 26), Convention on the Rights of the Child (Article 28), UNESCO Convention against Discrimination in Education (Articles 4) and African Charter on the Rights and Welfare of the Child (Article 11) supported the efforts of promoting the 
policy of fee-free education (UNESCO, 2014). National policies of many countries found it fair to influence fee-free policy for two major reasons. First, to ensure that poor and vulnerable children access quality education as affluent children. Second, to ensure effective financial management issued for provision of quality education (URT, 2015a; URT, 2016).

In Tanzania, Circular No. 5 of ETP of 2014 directed that primary and secondary education should be given freely by the government (URT, 2014). The circular No 5 of 2016 reads: "Provision of free education means learners will not pay any fee or other contributions that were being provided by parents or guardians before the release of the new circular" (URT, 2016). To ensure effective management of the finance disbursed by the government, various tools were put in actions such as the establishment of Financial Facility and Accounting Reporting System (FFARS) program and proper allocation of funds according to departments (URT, 2014 \& URT, 2015a, 2016). Moreover, the government insisted on accountability and transparency on the management of the disbursed finance for fee-free basic education through displaying the budget on the school notice boards, involving the school boards in the preparation of the budget and regular reading of the budget to the parents' meeting.

Tanzania has a long history of fee-free basic education policy since independence in 1961. The establishment of free education did not come into being mysteriously; rather, several international agencies influenced it. The notable international agencies include the Universal Declaration on Human Rights (Article 26), Convention on the Rights of the Child (Article 28), Convention on the Rights of Persons with Disabilities (Article 24), UNESCO Convention against Discrimination in Education (Articles 4) and African Charter on the Rights and Welfare of the Child (Article 11) (UNESCO, 2014). National, regional and international policies found it fair to make fee-free in basic education necessary for two major reasons. First, to ensure that poor and vulnerable children can access education equally as affluent children. Second, to ensure effective management of the disbursed government funds issued for the provision of quality education (URT, 2016).

According to Circular No. 5 of ETP, 2014, public bodies were directed to ensure that primary and secondary education (Basic Education) is given freely by the government as stated in the educational goal statements (URT, 2014). In that regard, circular No 5 of 2016 reads, "Provision of free education means pupils or students will not pay any fee or other contributions that were being provided by parents or guardians before the release of the new circular" (URT, 2014). Hence, under that circular, the regime provided knowledge without payment policy by replacing the former basic education financing system that involved costsharing between the education service user and the government. For instance, at the secondary school level, day scholars were initially charged a fee of $40,000 /=$ which was reduced to $20,000 /=$. Boarding scholars were paying $70,000 /=$ per year (URT, 2014).

Apparently, the old system of financing education by cost-sharing had no appropriate tools for financial resource management. The notable tools established under FFBE policy of 2014 includes Financial Facility and Accounting Reporting System (FFARS) program and proper allocation of funds according to departments such that, $35 \%$ of the total amount was disbursed for administration activities, 30 per cent for academic activities, 15\% for internal and external examination activities, 10 per cent for life insurance and $10 \%$ for maintenance activities (URT, 2014, 2015b, 2016). Moreover, the government insisted on accountability and transparency in using the disbursed finance for the operation of fee-free basic education including displaying a budget to the school notes boards. The national five years' development plan in Karatu district Council 2017/2018-2021/2023 indicates the implementing roles including sharing out of fiscal plan as well as apparent and answerable use of public moneys. In Karatu district, as in other parts of rural Tanzania, the policy of fee-free basic education is being implemented since 2016. Since then, the government became the major financing agent specifically in primary and lower secondary education.

Poor financial management policies and procedures result into embezzlement of financial resources in schools by heads of school and bursars (Adan and Orodho, 2015). Poor planning and budgeting among school organization also affects financial management, which would result into complication in reporting the revenues and the expenditures (Brimley, Versiegen \& Knoeppel, 2020). Appropriate budget helps to achieve the predetermined objectives through identifying key activities, 
mileposts, performance indicators, strategies and measures for proper financial use. One of major challenges experienced is that heads of schools face budget constrain due to inadequate funds (Njideka, 2020).

Internal control comprise of a system of procedures and methods with the objective to assure compliance with the principles of legitimacy, transparency, efficiency, effectiveness and proper management of school finances. Poor financial management and absence of budget reviews encourage the behaviour of people to supply the system with inaccurate information; as a result, people will have loopholes for financial embezzlement (Boddy, 2011). Therefore, constant review of the budget becomes one of the critical tools for solving poor control of financial resources and lack of budget reviews in public secondary schools. Moreover, budget reviews enhance financial control which would be important in ensuring that school resources are mobilized and disseminated effectively. Poor budget reviews result into poor monitoring and evaluation of financial resources in schools, which leads to poor implementation of education policies.

According to Onguko, Abdalla and Webber (2008), shortage of training for education leaders resulted into promotion of teachers to headship positions without undergoing any training. On the same note, Ogba and Igu (2014) argued that the quality of training acquired by heads of schools determines their administrative visions and missions.

Currently, some public secondary schools in Tanzania are faced by challenges of poor preparation of financial reports or recording of revenue and expenses in the daily books of accounts. Schools lack supporting documents for the revenue collected and the expenditures incurred (HakiElimu, 2017). In Clark and Sampson's (2008) view, financial resource management in most schools challenges heads of schools because many of them have little or no training or expertise on preparation of financial documents. It is also likely that the elected members of the school boards may be equally ill-equipped for the task of auditing financial documents. Therefore, follow up of schools' daily expenditure lags behind which provide a room for the head of schools to take advantage of misusing financial resources.

In De Beer and Rossouw's (2005) view, financial management in schools depends on the effective knowledge and skills of preparing financial records as poor records management leads into difficulties in effectively managing, developing and supervising financial resource. Therefore, effective record keeping in schools become a very important tool in managing financial resources. Moreover, quality task performance, task accomplishment and measurable outcomes are important expectations which depend on effective preparation of financial records. Without effective and proper preparation of financial records, it is impossible to ensure accountability and transparency which would be an important tool for holding heads of school and school bursars accountable.

\section{Methodology \\ Design and Approach}

The study employed the mixed research approach in collecting, analysing data and interpreting the data. This approach enabled the researchers to overcome weaknesses of each approach in order to provide a clear report as one approach in data collection may not be enough for better. Convergent parallel design was used in this study.

\section{Population and Sampling}

The study was conducted in Karatu District which had 29 public secondary schools from which six were randomly sampled. Out of 2441 students and 102 teachers from the sampled schools, 97 students and 50 teachers were selected through simple random sampling. Furthermore, 24 school board members, one District Educational Officer and six Heads of School participated in the focus group discussion.

\section{Instrumentation}

This study employed questionnaire, semi-structured interview and focus group discussion (FGD). The questionnaire and the interview schedule were employed to students and teachers while the FGD was employed to the rest of respondents. The questionnaire collected the quantitative data which was analysed descriptively using the Statistical Package for Social Science. On the other hand, qualitative data was collected through interview and focus group discussion and was analysed thematically.

\section{Validity and Reliability}

Validity was ensured through preparation of research instruments in a simple manner under the guidance of two research experts. Methodological triangulation, the use of the mixed approach ensured the reliability of findings. 


\section{Findings and Discussion}

Findings are presented in line with the research question which states: what are the challenges facing the implementation of fee-free basic education among public secondary schools in Karatu District?

Table 1 presents the summary of challenges facing the implementation of fee-free basic education policy among public secondary schools in Karatu District. Out of 102 sampled students, 70\% agreed that there is poor budget and control in schools. Furthermore, $78.3 \%$ indicated that deficit in school accounts is an outcry in the schools. Poor budgeting review was considered by majority (69\%) as a challenge. It is also important to note that $65.8 \%$ explained that lack of accountability is a challenge and $70 \%$ considered poor financial recording as a problem.

Out of 50 sampled teachers, $70 \%$ revealed that there is poor budgetary and controlling, 78\% indicated that there is deficit in school accounts, $70 \%$ showed that there is poor budget review, $68 \%$ indicated that there is lack of accountability and $70 \%$ perceived that there is poor financial recording.

Table 1: Challenges facing fee-free basic education policy on financial management

\begin{tabular}{lcccc}
\hline Statement & \multicolumn{2}{c}{ Students } & \multicolumn{2}{c}{ Teachers } \\
& Frequency & Percent & Frequency & Percent \\
\hline Poor budgetary and controlling & 68 & 70 & 35 & 70 \\
Deficit in school accounts & 76 & 78.3 & 39 & 78 \\
Poor budget review & 67 & 69 & 35 & 70 \\
Lack of accountability & 64 & 65.8 & 34 & 68 \\
Poor financial recording & 68 & 70 & 35 & 70 \\
\hline
\end{tabular}

Questionnaire findings were corroborated with the Focus Group Discussion (FGDs) findings. All participants in the FGDs acknowledged that poor budget review, deficit of school accounts are among challenges facing the fee-free basic education policy implementation in public secondary schools under investigation. These views concur with that of Njideka (2020) who found that heads of school are facing budget management challenges.

The interview schedule revealed that

The money brought is very little to run daily school activities. When it comes to the planning of school budget, school board members and heads of schools do prepare the school budget which is then projected depending on expected learners for the particular academic year (Anonymous, 2021).

Another respondent said: deficit of school accounts is the alarming constraint among others because we fail even to sit together to review the budget which could be used to guide school organizations in managing finance. The government provides $10 \$$ (2,500 TSHS) flat grant to each student per month without considering school location variability. For that matter, most schools located in peripheral areas suffer shortage or deficit of budget which contribute to poor performance academically.

The respondent continued to say:

In my school I have introduced projects of bee keeping, dairies and cafeteria to curb financial challenges from fee-free policy. The money found is used to buy teaching and learning materials, complementing the gap (Interview August, 2021).

Based on this standpoint, Kattan (2006) contends that deficit of school accounts in implementation of FFBE policy leads to challenges related to issues of sustainability.

Moreover, majority of teachers indicated that poor financial record is one of challenges facing financial management in public secondary schools. The findings resemble that of De Beer and Rossouw (2005) who argued that effective financial resource management depends on the effective knowledge and skills of preparing financial records.

\section{Conclusions and Recommendations Conclusions}

Implementation of fee-free education in Tanzania faces challenges which reduce the accuracy of reaching the government expected goals. Among the challenges are poor budget review, lack of financial training and poor accountability by school heads due to limited knowledge on financial management. The school board members do not have experience on accounting procedure which reduces the power of making follow up of daily school expenditure. 


\section{Recommendations}

The study recommends that the government should ensure that key stakeholders, especially school heads, are well equipped with appropriate skills on financial management in order to curb challenges in implementation of the fee-free basic education among public secondary schools in Karatu District. This will enable school heads to implement the financial management effectively.

\section{References}

Adan, M. A., \& Orodho, J. A. (2015). Constraints of implementing free secondary education in Mandera West Sub-County, Mandera County, Kenya. Journal of Education and Practice, 6(9), 102-111.

Boddy, D. (2011). Management of financial resources: An Introduction, ( $5^{\text {th }}$ ed.). England; Pearson Education Limited.

Brimley, J. R., Versiegen, D. A \& Knoeppel, R. C. (2020). Finance Education in a climate of change. (13 ${ }^{\text {th }}$ ed.). New York: NY. Pearson Education Inc.

Caine, R. (2011). Educational access and poverty reduction: The case of Ghana1991-2011. International Journal and Educational Development, 31( ), 38-349.

Clark's, B.D \& Sampson. V. (2008). Assessment of the ways students generate arguments in science education: Current perspectives and recommendations or future directions. From https://edisciplinas. Usp.br

Creswell, J. W., \& Plano Clark, V. L. (2011). Designing and conducting mixed methods research $\left(2^{\text {nd }}\right.$ ed.). Thousand Oaks, CA: Sage Publications, Inc.

De Beer, A., \& Rossouw, D. (2005). Focus on operational management: $A$ generic approach. Cape Town: Juta.
HakiElimu, (2017). The impact of the implementation of fee-free education policy on basic education in Tanzania: $A$ quantitative study. From http://ww w.h akielimu.org.

Kattan, R. B. (2006). Implementation of free basic education policy. Open Journal of Social Science, $6(5), \ldots \ldots$ From https://www.

Scirp.org

Njideka, G. (2020). Management competency needs of principals for effective administration of secondary schools in Nigeria. International Journal of Advanced Research in Education \& Technology, 3(3), 61-67.

Ogba, F. N.\& Igu, N. C. (2014). Realizing quality education in Nigeria: The need to revitalize secondary education. Journal of Education Research, 2 ( ), 57-64.

Onguko, B., Abdalla, M. \& Webber, C.F. (2008). Mapping principal preparation in Kenya and Tanzania. Education Management, Administration and Leadership, 46, 715-726.

UNESCO (2014). The right to education: law and policy review guidelines 2014. From https

URT (2014). Sera ya elimu na mafunzo. Ministry of Education and Vocational Training. Dar es Salaam, Tanzania.

URT, (2015a). Ministry of Education, Science, Technology. From https://www.moe.go.tz

URT, (2015b). Sera ya elimu na mafunzo. Ministry of Education and Vocational Training. Dar es Salaam, Tanzania.

URT (2016). Waraka wa elimu namba 3 wa mwaka 2016 kuhusu utekelezaji wa elimumsingi bila malipo. 